Diabetes require mandatory correction of antidiabetic therapy. This is an important task at the stage of convalescence, when the patients have a stable condition and sufficient level of blood oxygen saturation.

The first step in adjusting therapy may be to cancel or reduce the dose of prandial insulin and to add metformin to the treatment regimen under the control of fasting and postprandial glycemic levels. If patient status needs to intensify therapy, the second step may be the use of the fixed combination of insulin glargine and lixisenatide (Soliqua Solostar) in combination with metformin. Both options of hypoglycemic therapy are quite effective, well tolerated by patients and can be used according to the individual indications.

The use of the combination of Soliqua SoloStar and metformin can lead to significant decrease of glycosylated hemoglobin level in patients with poor glycemic control in the previous stage of treatment.

The duration of Diabetes and glycemic control before the Covid-19 onset can affect the time of reaching targets of glycemic control at the period of convalescence.

DOI https://doi.org/10.30525/978-9934-26-113-8-17

\title{
КЛІНІЧНІ ОЗНАКИ ТА ПАТОГЕНЕТИЧНІ ЧИННИКИ ПОСТКОВІДНОГО КОЛІТУ
}

\author{
Томашкевич Г. I. \\ кандидат медичних наук, \\ дочент кафедри пропедевтики внутрішньої медицини \\ Вінницький національний медичний університет імені М. І. Пирогова \\ Ошарова А. М. \\ студентка \\ Вінниџький національний медичний університет імені М. І. Пирогова \\ м. Вінниця, Україна
}

Актуальність. Шлунково-кишкові симптоми Covid-19: нудота, блювання, відсутність апетиту, діарея, можуть виникати до появи пірексії, респіраторних симптомів чи одночасно 3 ними. Результати досліджень [2, с. 3] демонструють наявність вірусної РНК у калі або анальних/ректальних мазках пацієнтів з Covid-19. 39 (53,4\%) пацієнтів Covid-19 мали позитивні результати на SARS-CoV-2 PHK в калі, тривалістю від 1 до 12 днів. Попередне дослідження SARS-CoV 
показало, що вірусна РНК може бути виявлена через 30 днів у калі реконвалесцентів. Електронна мікроскопія на зразках біопсії та розтину показали активні реплікації вірусів як у тонкому, так і у товстому кишечнику.

Кишкові симптоми можуть з'являтися на різних етапах перебігу та лікування Covid-19. Поява діареї, болю в животі, метеоризму можуть бути проявами антибіотикасоційованої діареї, псевдомембранозного коліту. Аналіз SHAP показує, що старший вік, знижений рівень альбуміну, вищий рівень креатиніну та вищий рівень лейкоцитів $\epsilon$ найбільш асоційованими ознаками смертності, що узгоджується 3 існуючими клінічними висновками [3, с. 3].

Мета: Визначити частоту уражень шлунково-кишкового тракту у хворих на COVID-19 з метою подальшої розробки критеріїв ранньої діагностики, ефективного лікування та профілактики патології травної системи.

Матеріали і методи: Проведений мета аналіз 50 історій хвороб пацієнтів: 28 чоловіків (56,2\%) та 22 жінок $(43,8 \%)$. Середній вік пацієнтів становить 50,5 років.

Результати: Серед 50 хворих, що перебували на стаціонарному лікуванні 2 (4\%) мали легкий перебіг; 45 (90\%) - середньої тяжкості; 3 (6\%) - важкого ступеню тяжкості. Ознаки ураження ШКТ діагностувалися у пацієнтів віком 51-75 років. Ознаки ураження ШКТ частіше діагностуються у пацієнтів із перебігом середньої важкості COVID-19 - 25 хворих (50\%), 3 них: втрата апетиту - 19 (42\%); нудота - 9 (18\%); больовий синдром - $3(6 \%)$; метеоризм - $3(6 \%)$; діарея - 5 (10\%) випадків. Спостерігаються також підвищення рівнів біохімічних показників: загального білірубіну у 9 пацієнтів (18\%); АЛТ 4 хворих (8\%); АСТ - 2 хворих (4\%); всіх показників - 6 хворих (12\%). Загалом - у 21 пацієнта (42\%). 3 меншою частотою (10\%) скарги зі сторони ШКТ мали місце у пацієнтів із важким перебігом та у групі 3 легким перебігом захворювання (33\%). Під час стаціонарного лікування у 5 пацієнтів розвинулись важкі ускладнення 3 боку шлунковокишкового тракту. Клінічна картина перебігу суттєво не відрізнялась: діарея, наявність слизу, крові в калі, біль у черевній порожнині, метеоризм, гіпертермія від субфебрильних цифр до гектичної гарячки з ознобами, схуднення. У однієї пацієнтки посмертно був встановлений діагноз псевдомембранозного коліту, друга пацієнтка померла від поліорганної недостатності, третя - лікувалася тричі з приводу рецидивів псевдомембранозного коліту. У 3-х пацієнтів чоловічої статі виникнення кишечної симптоматики спостерігалось через 2-3 тижні після виписки із 
стаціонару. Двоє 3 них були прооперовані 3 приводу токсичного мегаколон. У одного пацієнта була проведена ендоскопічна ревізія черевної порожнини та іiі дренування, у другого тотальна ектомія товстого кишечника. Третій пацієнт лікувався консервативно відповідно до існуючих рекомендацій $[1$, с. 3$]$.

Неодноразові тестування на наявність токсинів Clostridioides Difficile мали негативний результат у 5 пацієнтів (83\%).

Висновки: Частота появи суб'єктивних ознак з боку травної системи становить 50\%, у 42\% пацієнтів зафіксовані ознаки синдрому жовтяниці та цитолізу. Ознаки ураження слизової оболонки шлунково-кишкового тракту на початку захворювання не обумовлює його важкий перебіг. Акцентуація уваги на ранніх ознаках COVID-19, у тому числі, зі сторони травної системи, дозволяє вчасно запобігати поширенню коронавірусної інфекції, діагностувати захворювання та виникненню ускладнень, проводити диференційну діагностику можливих ускладнень COVID-19, повноцінно розуміти клінічну картину хвороби, надавати пацієнтам відповідну медичну допомогу.

\section{Література:}

1. Richard L Nelson, Katie J Suda, Charlesnika. Antibiotic Treatment for Clostridium Difficile-Associated Diarrhoea in Adults, Cochrane Database Syst Rev 2017 Mar 3; 3(3): CD004610. doi: 10.1002/14651858.CD004610.pub5. 2017.

2. Sunny H Wong, Rashid NS Lui, Joseph JY Sung. Covid-19 and the digestive system. https://doi.org/10.1111/jgh.15047. 2020.

3. Yui-Lun Ng, Michelle C. K. Lo, Kit-Hang Lee, Xiaochen Xie, Thomas N. Y. Kwong, Margaret Ip, Lin Zhang, Jun Yu, Joseph J. Y. Sung, William K. K. Wu, Sunny H. Wong, Ka-Wai Kwok. Development of an OpenAccess and Explainable Machine Learning Prediction System to Assess the Mortality and Recurrence Risk Factors of Clostridioides Difficile Infection Patients. Advanced Intelligent Systems. Volume 3, Issue 1. 2020. 